\title{
UK under attack over lab 'efficiency' review
}

London. Britain's Royal Society has published a swingeing attack on outline proposals to reorganize 53 publicly funded research laboratories through a massive programme of 'rationalization'.

The proposals were the result of a threemonth study of the laboratories by a group of government 'efficiency experts'. Their report, published in April, backed down from initial suggestions that many of the laboratories might be privatized; but it still suggested wide-ranging changes to avoid what the team described as duplication and overlap (see Nature 368, 681; 1994).

But the Royal Society, in one of the strongest criticisms it has ever made of the government, claims that the proposals are at best a misunderstanding of the role of the laboratories in providing a scientific underpinning to the nation's industrial activities, and at worst a dangerous exercise that could undermine the country's science base.

"The Scrutiny Review has not been able to produce coherent, well-judged recommendations," the society says in a statement published this week as its response to the government's request for comments on the review's proposals.

Pointing out that British science is already in the middle of upheavals resulting from last year's white paper on science, the society says that there is "no case for pro- ceeding now with what it proposes, which would entail extensive and costly disruption for no obvious benefit".

The statement describes efforts to present the review purely as an exercise in management efficiency, divorced from questions about the mission of the laboratories it studied, as "disingenuous".

It claims that the team of civil servants that carried out the review was unable to give "even an approximate indication of the scale of savings that its proposals might achieve". Nor, it claims, was the team able to demonstrate "the existence of real scientific overlap on a scale which would warrant the disruption of major restructuring".

The Royal Society says that it is unenthusiastic about both models that the team suggests as a basis for restructuring. One would group research agencies according to their field of interest; the others would seek groupings based on regional proximity.

It also claims that the report fails to acknowledge the large institutional and social costs of restructuring, and that the review "illustrates the dangers of concentrating on financial issues without taking the trouble to obtain expert disinterested advice about the scientific and technological issues".

Sir Francis Graham-Smith, the director of the Nuffield Radio-astronomy Laboratories at Jodrell Bank, and physical sciences secretary of the Royal Society, says that the review team "has not understood the scientific side of what they are saying, perhaps because they were initially sent in with heavy boots labelled 'privatization', even though they then backed off to concentrate on 'rationalization"”.

The review team's proposals are thought to have come in for widespread criticism during the public consultation period on its recommendations, which ends tomorrow (11 November). The Institution of Professionals, Managers and Specialists, for example, the trade union that represents many of the scientists employed in the laboratories being assessed, said that its conclusions attempt to resolve genuine conflicts facing the laboratories "in favour of government market ideology, rather than the effectiveness of public science".

Addressing a House of Commons select committee two weeks ago, David Hunt, the minister for science, said that he supported the main goal of the efficiency review, namely to ensure that more money was spent on science and less on bureaucratic administration. But he also said that he had an open mind on the review group's proposals, and would not reach firm conclusions on future action before he had considered the various comments that had been made on its recommendation.

David Dickson

\section{Lay panel backs gene-modified plants but urges stricter monitoring}

London. Britain's first 'consensus conference', intended to canvas public opinion on plant biotechnology has resulted in calls for clear and meaningful labelling of genetically modified food products and a stricter system for monitoring genetically engineered crops.

These were the main recommendations of a group of 16 individuals, chosen from a wide range of ages and backgrounds as members of a 'lay panel', which last week published a preliminary report after two days of discussion and oral evidence from a range of biotechnology experts.

The experiment was funded by the Biotechnology and Biological Sciences Research Council. According to Tom Blundell, the council's chief executive, last week's conference, which was organized by the Science Museum on the council's behalf, cost more than $£ 80,000$, but it was "worth every penny".

The consensus conference was based on similar exercises elsewhere in Europe and in the United States. In Denmark in particular consensus conferences on topics such as food irradiation, mapping of the human genome and genetically manipulated animals have been used in public policy-making.

The British lay panel had undergone two weekends of intensive briefing on plant biotechnology. Among the seven key questions they highlighted were: what are the principal risks and benefits of modern plant biotechnology; what impact could it have on the consumer and the environment; why is patenting so important; and what are the prospects for effective regulation?

Opening the conference, John Durant, assistant director of the Science Museum,

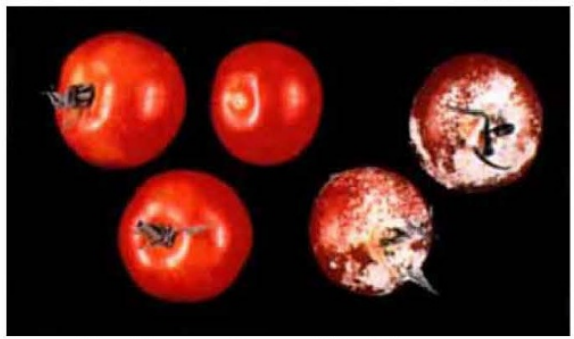

Long-life: Zeneca's modified tomatoes (left) after four weeks' storage.

said that the Danish experience with consensus conferences had shown that "it is an important enough process for us to try and see if it can play a role in the United Kingdom".

In its report the panel emphasized the potential benefits and risks of plant biotechnology. Benefits include plant varieties with higher yields, tastier and more nutritional fruits and vegetables, less use of herbicides and pesticides; but the panel also pointed out the dangers of disruption to the food chain, the creation of new 'superweeds' and increased monoculture in agriculture.

One of its main recommendations centred on the right of consumers to choose whether or not to consume genetically modified food products. This would require "clear meaningful labelling", with national and international uniformity on procedures being the ultimate aim. The panel concluded that such labelling should be required by law, and not remain voluntary.

Several of the experts disagreed. Lord Howie of Troon, for example, chairman of a House of Lords select committee that recently complained of excessive regulation of the British biotechnology industry, said that labelling would signal that the products were dangerous. While welcoming the consensus method, he added "we must recognize that it doesn't have ultimate value".

The panel also felt that, despite its acknowledged stringency, there was "still room for improvement" in the United Kingdom's system of regulatory control of genetic engineering. In particular, it called for the appointment of an "independent ombudsman" to monitor investigations of the adequacy of the regulation, and for a government minister to oversee the development of monitoring procedures.

Maggie Verrall 